\title{
Penguatan Moderasi Beragama melalui Forum Persaudaraan Lintas Iman (Forsa) Kabupaten Banyumas pada Masa Pandemi Covid-19
}

\author{
Muhamad Riza Chamadi ${ }^{1 *}$, Dwi Nugroho Wibowo ${ }^{1}$, \\ A. Ilalqisni Insan ${ }^{1}$, Musmuallim ${ }^{2}$, Ahmad Yusuf \\ Prasetiawan $^{2}$ \\ ${ }^{1}$ Fakultas Biologi, Universitas Jenderal Soedirman, \\ Purwokerto - Indonesia \\ ${ }^{2}$ Fakultas Teknik, Universitas Jenderal Soedirman, \\ Purwokerto - Indonesia
}

Article Information

Submited April 26, 2021

Revised Mei 12, 2021

Accepted Juni 28, 2021

Published Juli 31, 2021

\begin{abstract}
Some groups often use teenagers' interest in religious studies during the Covid-19 pandemic to indoctrinate radical and intolerant views. Religious moderation is a teaching concept that contains values of religious tolerance and reduces the prevalence of religious intolerance and extremism. This community service aims to increase understanding of religious moderation for interfaith youth through the Banyumas Interfaith Brotherhood Forum (Forsa). This community service uses community education methods through workshop methods and field practices. The service activities took place in eight sessions which generally consisted of pre-test and introduction sessions, workshop sessions, field practice sessions and electronic media orations. The workshop session contained material about diversity, religious moderation, cases of intolerance in Indonesia, and being wise in social media. The seventh session took moderation practice by distributing masks and necessities to managers of places of worship in Banyumas and small communities affected by Covid-19. The eighth session was a moderation message oration through Rama FM radio. This community service activity results show an increase in participants' understanding of religious moderation from a medium-scale to a large scale. Field practice shows the participants' enthusiasm in caring for diversity through actual actions in a pluralistic society.

Keywords: Religious Moderation; Covid-19; Interfaith Community

Sebagian kelompok memanfaatkan ketertarikan remaja terhadap pendalaman agama di masa Pandemi Covid-19 untuk mendoktrin paham radikal dan intoleran. Moderasi beragama merupakan konsep ajaran yang memuat nilai-nilai toleransi beragama dan mereduksi maraknya intoleransi dan ekstremisme beragama. Pengabdian masyarakat ini bertujuan untuk meningkatkan pemahaman moderasi beragama bagiremaja lintas iman melalui Forum Persaudaraan Lintas Iman (Forsa) Banyumas. Pengabdian masyarakat dilakukan dengan metode edukasi masyarakat melalui metode workshop dan praktik lapangan. Kegiatan pengabdian berlangsung dalam delapan sesi yang secara umum terdiri dari sesi pre-test dan perkenalan, sesi workshop, erta sesi praktik lapangan dan orasi media elektronik. Sesi workshop berisi pemberian materi tentang kebhinekaan, moderasi beragama, kasus-kasus intoleransi di Indonesia, dan cerdas dalam bermedia sosial. Sesi ketujuh berbentuk praktik moderasi dengan membagikan masker dan sembako untuk para pengelola tempat ibadah di Banyumas dan masyarakat kecil terdampak Covid-19. Sesi kedelapan berupa orasi pesan moderasi melalui radio Rama FM. Hasil kegiatan pengabdian masyarakat ini menunjukkan peningkatan pemahaman moderasi beragama peserta dari skala medium menjadi skala tinggi. Praktik lapangan menunjukkan antusiasme peserta dalam merawat kebhinekaan melalui aksi nyata di lingkungan masyarakat yang majemuk.
\end{abstract}

Kata Kunci: Moderasi beragama; Covid-19; Komunitas Lintas Iman

\footnotetext{
*Korespondensi Penulis: Muhamad Riza Chamadi, email: riza.chamadi@gmail.com Alamat Korespondensi penulis, Fakultas Biologi Universitas Jenderal Soedirman, Purwokerto - Indonesia

Copyright (C) 2021 Muhamad Riza Chamadi, Dwi Nugroho Wibowo, A. Ilalqisni Insan, Musmuallim, Ahmad Yusuf Prasetiawan
} 


\section{Pendahuluan}

Moderasi beragama merupakan sikap keagamaan seseorang yang mengedepankan asas moderat, toleran, dan inklusif dalam beragama. Sikap keagamaan tersebut menjadi kunci utama suatu individu atau golongan untuk dapat hidup dalam masyarakat yang plural. Masyarakat Indonesia merupakan masyarakat multikultural yang memiliki keragaman budaya, etnis, suku, bahasa, serta agama yang dapat menjadi integrating force dalam mengikat nilai-nilai multikultural di masyarakat. Namun seperti dua mata pisau, kemajukan yang tidak terkawal dengan baikjustru dapat menciptakan gesekan antar nilai budaya, etnis, suku, ras, serta agama yang ada di masyarakat (Akhmadi, 2008).

Remaja merupakan masa di mana individu mulai mencari dan menemukan identitas diri mereka. Perkembangan kemajuan teknologi atau orang lazim menyebutnya era digital menjadi tantangan dalam perkembangan psikologi remaja. Bemacam-macam konten di media sosial yang berisi, hoax, bullying, konten sara, hingga radikalisme beragama dapat berujung pada gerakan transnasional yang menolak sistem negara (Faiqah \& Pransiska, 2018). Isu agama merupakan salah satu isu sensitif khususnya di kalangan remaja dan dapat berimbas pada maraknya ujaran kebencian dan radikalisme agama.

Pada masa awal kemunculan Coronavirus Disease 2019 (Covid-19) banyak beredar isu hoax, teori konspirasi, serta penyimpangan persepsi keagamaan suatu kelompok terhadap Covid-19 itu sendiri. Menurut Iswandi Syahputra yang dikutip Musa Maliki, awal munculnya Covid-19 Menciptakan dua perspektif kelompok Islam: pertama, perspektif Jabariah. Perspektif
Jabariah menganggap bahwa Covid-19 mutlak kuasa Allah. Umat muslim menurut kelompok ini idealnya lebih takut terhadap perintah Allah daripada harus menyesuaikan fiqih ibadah dengan protokol kesehatan. Perspektif Jabariyah sangat membahayakan untuk dikonsumsi masyarakat terutama remaja milenial. Kedua, perspektif Qadariyah. Perspektif Qadariyah merupakan perspektif mayoritas umat Islam yang merespon Covid-19 dengan ikhtiyar melalui berbagai cara dan tidak menyimpang dengan koridor agama (Maliki, 2020).

Remaja merupakan fase perkembangan dalam rentang usia dari 12 sampai 23 tahun. Fase tersebut terbagi lagi menjadi fase pra remaja, fase remaja awal, dan fase remaja lanjut (Diananda, 2018). Remaja memiliki karakter perkembangan yang dinamis. Pada usia remaja, seseorang berusaha menemukan konsep kebenaran terhadap sebuah kepercayaan dan konsep ketuhanan. Remaja akan mendapatkan ketenangan psikis jika mereka mampu menemukan kemapanan konsep ketuhanan dengan cara yang baik dan benar. Sebaliknya, keyakinan ketuhanan dan keagamaan remaja akan mudah goyah apabila mereka mendapatkan pemahaman tersebut dengan cara yang tidak benar, ataupun melalui informan yang salah (Umami, 2019).

Mahasiswa merupakan bagian dari remaja fase remaja lanjut. Hasil penelitian menunjukkan bahwa tingkat pemahaman radikalisme agama yang dimiliki oleh mahasiswa berada pada level "sedang". Kondisi ini menunjukkan bahwa mahasiswa dapat terpapar dan terpengaruh oleh radikalisme karena pemahamannya yang kurang memadai. Selain meningkatkan kesadaran dan pengetahuan tentang radikalisme, pencegahan internal dari 
dalam diri mahasiswa sangat penting. Perlu penguatan keimanan dan ketaqwaan agar menjadi benteng dalam diri mahasiswa untuk mencegah radikalisme agama (Widyaningsih et al., 2021).

Untuk mereduksi berbagai tantangan tersebut di atas, tim pengabdian masyarakat Universitas Jenderal Soedirman bermitra dengan Forum Persaudaraan Lintas Iman (Forsa) Kabupaten Banyumas melakukan pengabdian dengan bentuk edukasi masyarakat. Forsa merupakan perkumpulan remaja dan masyarakat lintas agama. Forsa Banyumas memiliki komitmen yang tinggi dalm konteks kebhinekaan dan menjaga NKRI. Pengabdian berupa edukasi masyarakat ini kami beri judul: Penguatan Moderasi Beragama melalui Forum Persaudaraan Lintas Iman (Forsa) Kabupaten Banyumas pada Masa Pandemi Covid 19.

\section{Metode Pelaksanaan}

Metode pelaksanaan Kegiatan pengabdian masyarakat ini menggunakan metodependidikanmasyarakatyangbertujuan mengembangkan, menyebarluaskan, dan menerapkan iptek untuk meningkatkan kemampuan seseorang dalam dalam merespon berbagai masalah serta mencari penyelesaiannya (Riduwan, 2016). Kegiatan pengabdian ini kami selenggarakan dalam bentuk workshop dan praktik lapangan. Kegiatan terdiri dari 8 sesi. Sesi kesatu sampai sesi keenam terselenggara pada hari Minggu, tanggal 2 Februari 2020 dalam bentuk workshop kebangsaan. Workshop terselenggara secara luring sebelum adanya pembatasan fisik dan wilayah. Workshop terselenggara di Pondok Pesantren Darul Mujahirin, Ajibarang Banyumas sebagai salah satu pondok pesantren yang menjadi mitra kegiatan Forsa.

Kegiatan Sesi 7 dan 8 pengabdian masyarakat dalam bentuk praktik moderasi beragama secara langsung ke masyarakat. Kegiatan ini terlaksana pada hari Selasa tanggal 12 Mei 2020. Kegiatan sesi 7 diikuti oleh para anggota Forsa yang melakukan turun jalan (turjal) dengan membagikan masker dan sembako pada masyarakat di Purwokerto, khususnya para pengelola rumah ibadah, pedagang kaki lima, tukang becak, dan masyarakat ekonomi bawah yang secara langsung terdampak Covid-19. Kegiatan sesi 8 sebagai sesi terakhir yaitu berupa siaran langsung edukasi masyarakat dengan tema moderasi beragama pada situasi Covid-19, oleh tim pengabdian masyarakat Universitas Jenderal Soedirman melalui chanel radio Rama FM.

Kegiatan pengabdian masyarakat tim Universitas Jenderal Soedirman dengan mitra Forsa Banyumas terselenggara dengan penerapan protokol Covid-19 secara ketat. Peseta workshop sesi 1-6 berjumlah 50 (lima puluh) orang yang terdiri dari remaja dari pemeluk agama yang berbeda serta remaja pemeluk penghayat kepercayaan yang berdomisili di Kabupaten Banyumas. Kegiatan sesi 1 dilakukan secara luring, dikarenakan pada tanggal 2 Februari 2020 belum diberlakukan pembatasan kegiatan masyarakat oleh Pemerintah Kabupaten Banyumas. Kegiatan sesi 7 berlangsung dengan luring dalam bentuk pembagian masker dan sembako yang dilaksanakan oleh peserta sesi 1-6 dengan menerapkan protokol Covid-19. Sedangkan sesi 8 terlaksana dalam bentuk on-air. 


\section{Hasil dan Pembahasan}

Moderasi beragama merupakan sebuah konsep beragama yang inklusif dalam masyarakat multikultural. Moderasi beragama berbeda dengan liberalisasi beragama. Gagasan moderasi beragama muncul sebagai respon terhadap berbagai problem yang dihadapi umat beragama di Indonesia. Problem keberagamaan tersebut secara umum terbagi atas problem sosial, budaya, serta agama (Mubarok \& Rustam, 2018). Islam sebagai agama mayoritas di Indonesia, sering menjadi pusat perhatian dalam menyoal moderasi beragama. Ajaran Islam yang kompleks melahirkan berbagai interpretasi Islam yang dapat memicu gesekan sosial, baik antar umat Islam maupun antar umat beragama (Busyro et al., 2019).

Pada situasi pandemi Covid-19, salah satu sektor fundamental yang menerima dampak signifikan adalah sektor ekonomi. Dampak ekonomi dari adanya pandemi secara langsung tidak hanya berimbas pada penurunan ekonomi makro, melainkan juga berimbas pada ekonomi kelas mikro, usaha kecil, dan menengah (Pakpahan, 2020). Kelemahan ekonomi merupakan celah masuknya pemahaman intoleran dan radikal di tengah masyarakat agama. Sebagai contoh, maraknya gerakan ekstremisme Islam di Timur Tengah meulai muncul bersamaan dengan intervensi ekonomi negara Barat di negara-negara Arab (Abdullah, 2016).

Potret kerentanan beragama pada situasi pandemi Covid-19 menjadi pertimbangan dalam menentukan sesi kegiatan pengabdian ini. Tim pengabdian membagi kegiatan menjadi delapan sesi dari tema utama yaitu penguatan moderasi beragama melalui Forum Persaudaraan Lintas Iman (Forsa) Kabupaten Banyumas pada Masa Pandemi Covid 19.
Kegiatan pertama berbentuk workshop yang terbagi menjadi 6 sesi. Sesi kesatu merupakan tahap pra instruksional. Kegiatan sesi kesatu berisi pre-test pemahaman moderasi beragama dan literasi digital, serta warming up sebagai tahap elaborasi materi workshop. Sesi kedua masuk pada tahap instruksional berbentuk pemberian maateri workshop. Materi pada sesi kedua berisi teori-teori kebhinekaan. Sesi ketiga berisi pemaparan materi dasar-dasar moderasi beragama. Sesi keempat berupa materi studi kasus potret intoleransi di Indonesia. Sesi kelima berisi materi media literasi digital. Sesi keenam merupakan sesi penutup berbentuk post test sebagai pengukur tingkat pemahaman peserta antara pra workshop dengan pasca workshop.

Kegiatan kedua dalam pengabdian masyarakat ini berbentuk praktik lapangan. Praktik lapangan masuk pada sesi ketujuh dan sesi kedelapan. Bentuk kegiatan sesi ketujuh yaitu kegiatan membagikan sembako dan masker kepada masyarakat Banyumas. Sasaran kegiatan ini adalah para pengelola rumah ibadah di kota Purwokerto dan desadesa di Banyumas. Sesi kedelapan sebagai sesi penutup rangkaian pengabdian berupa orasi media. Kegiatan ini terselenggara melalui siaran on-air di radio swasta. Materi yang disampaikan yaitu refleksi keagamaan di tengah situasi pandemi Covid-19.

Berikut merupakan deskripsi kegiatan masing-masing sesi beserta analisis hasil kegiatan:

\section{Sesi 1}

Sesi pertama dimulai oleh MC melalui acara pembukaan formal. Hadirin secara bersama menyanyikan lagu Indonesia Raya. 
Setelah itu, acara disi dengan sambutansambutan. Sambutan pertama disampaikan oleh Budi Rohadi sebagai wakil presidium Forsa Banyumas. Sambutan kedua diberikan oleh Muhamad Riza Chamadi sebagai ketua tim pengabdian masyarakat Universitas Jenderal Soedirman. Setelah acara seremonial selesai, kegiatan berlanjut pada pengenalan tim pengabdian masyarakat sekaligus narasumber kegiatan workshop yang akan berlangsung. Peserta workshop merupakan remaja yang terdiri dari pelajar dan mahasiswa. Anggota IPNU IPPNU Pengurus Anak Cabang (PAC) Ajibarang mewakili pelajar Islam. Remaja anti asuhan Kristen Siloam Purwokerto menjadi wakil remaja kristen.

Unsur mahasiswa diwakili oleh mahasiswa-mahasiswa IAIN Purwokerto dan mahasiswa dari Universitas Jenderal Soedirman yang menganut keyakinan penghayat kepercayaan. Kegiatan ini terselenggara melalui protokol kesehatan pencegahan Covid-19 yang ketat. Kegiatan bertempat PonPes Darul Mujahirin Desa Ajibarang Kecamatan Ajibarang Banyumas, Workshop berlangsung di ruang aula Pondok Pesantren. Waktu pelaksanaan kegiatan ini pada Hari Minggu, 2 Februari 2020.

Sesi pertama kegiatan ini dimulai dengan pre-test wawasan keindonesiaan dan literasi digital. Pre-test berisi pilihan ganda dengan empat pilihan jawaban. Masingmasing jawaban test dapat mengukur tingkat pemahaman peserta workshop. Pre-test sangat cocok digunakan untuk menyelidiki dan menguji pemahaman seseorang terhadap suatu masalah. Hasil skor pre-test sebagai kovariat biasanya memberikan analisis yang lebih tepat dan informatif (Dugard \& Todman, 1995). Hasil pre-test menunjukkan tingkat pemahaman peserta workshop terhadap dua variabel masalah berada pada posisi medium atau sedang. Hasil test ini yang menjadi rujukan untuk tim pengabdian masyarakat meneruskan kegiatan menuju sesi selanjutnya.

Sesi kesatu ditutup dengan kegiatan perkenalan dan pemanasan fisik melalui ice breaking. Pemanfaatan kondisi psikologi peserta sebelum memulainya acara menggunakan ice breaking dapat mengoptimalkan kesehatan psikis peserta dan kekuatan konsentrasi mereka pada suatu pelatihan (Rogers \& Brig, 2002). Tim pengabdian masyarakat mengelola Ice breaking sebagai media perkenalan masingmasing peserta khususnya yang berasal dari latar belakang yang berbeda.

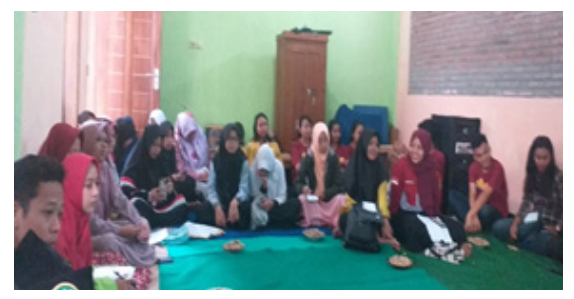

Gambar 1: Peserta Workshop Media Literasi Digital

\section{Sesi 2}

Sesi kedua masuk pada tahap instruksional workshop. Materi kebhinekaan dan keindonesiaan menjadi materi pada sesi kedua. Materi disampaikan oleh Musmuallim, dosen Mata Kuliah Wajib Umum (MKWU) dari Fakultas Teknik Universitas jenderal Soedirman. Konsep "Bhinneka" merupakan pengakuan masyakarat Indonesia terhadap keragaman. Keragaman dalam berbhineka merupakan keragaman yang bersifat multikulturalisme. Indonesia merupakan negara dengan beraneka ragam suku, bahasa, 
budaya, serta agama. Konsep kedua dari konsep kebhinekaan adalah interpretasi frasa "Tunggal Ika". Yaitu kesadaran masyarakat multikultural terhadap hakikat keberadaan mereka pada suatu bangsa. Kesadaran tersebut menumbuhkan rasa ingin bersatu dan hidup bersama dalam kemajemukan (Pursika, 2009).

Konsep Bhineka Tunggal Ika ditinjau dari aspek nilai (aksiologis) merupakan nilai kebangsaan Indonesia yang selalu menjadi pijakan sekaligus cita-cita bernegara. Pertemuan antara kata "Bhineka" dengan "Tunggal Ika" memposisikan sebuah keanekaan yang identik dengan perbedaan, bersatu dalam kemajemukan dengan visi hidup bersama. Kebhinekaan menjadi spirit dalam merumuskan dasar negara Indonesia yaitu Pancasila. Pancasila dengan lima silanya merupakan kausa material yang yang menjadi dasar perumusan keraturan perundangan di Indonesia (Latif, 2011).

Kegiatan sesi kedua berlangsung selama 90 menit. Materi diberikan oleh pemateri selama durasi 45 menit. Sedangkan 45 menit lainnya digunakan untuk tanya jawab interaktif. Materi kebhinekaan menunjukkan angka-angka kemajemukan bangsa Indonesia berdasarkan suku, bahasa, budaya, agama, serta keadaan geografis wilayah Indonesia. Pertanyaan yang muncul dalam sesi kedua yaitu tentang bagaimana generasi muda memposisikan diri dalam kerangka kebhinekaan di Indonesia, serta bagaimana peran remaja dalam menanggulangi kasus intoleransi. Konklusi dari materi kebhinekaan adalah deskripsi cara-cara generasi muda agar memiliki pemahaman yang baik dalam merawat kebhinekaan. Landasan spiritual pemuda menjadi landasan ideal dalam membangun pondasi inklusifitas bernegara dan beragama di negara Pancasila.

Hakikat kebinekaan merupakan semangat moral, rasional, intelektual, serta semangat dalam hal kepercayaan terhadap Tuhan Yang Maha Esa. Secara psikologis, manusia merupakan makhluk adikodrati yang dapat menangkap dengan baik kebutuhan moral spiritual melalui keyakinan adanya Tuhan, kekuatan intelektual, kekuatan rasional disertai moral yang baik (Jumala, 2019).

\section{Sesi 3}

Sesi ketiga yaitu sesi instruksional kedua. Materi dalam sesi ketiga tentang konsep moderasi beragama. Persinggungan antara nilai agama dengan nilai sosial kemasyarakatan melahirkan berbagai interpretasi agama. Sebagai contoh dalam Islam, kelahiran paham radikal merupakan anti klimak dari dialektika Islam yang syarat akan keilmuan dan moral yang baik. Perbedaan interpretasi Islam salah satunya terjadi pada dialektika para filsuf muslim abad ketujuh masehi. Perbedaan cara kerja epistemologi ilmuan muslim merjadi hazanah perbendaharaan interpretasi dalam Islam Berbeda dengan hazanah klasik, perbedaan interpretasi pada masa kontemporer melahirkan gerakan pragmatisme dan ekstremisme beragama (Faiqah \& Pransiska, 2018).

Moderasi beragama atau Islam wasathiyah merupakan respon terhadap ekstremisme kelompok dalam Islam. Moderasi beragama merupakan aktualisasi sikap keberagamaan yang inklusif dalam kerangka Islam rahmatan lil 'alamin (Shihab, 2019). 
Kecerdasan spiritual dan pemahaman tauhid yang kuat merupakan basis utama dalam mewujudkan moderasi beragama di Indonesia (Juhri, 2020). Konsep moderasi atau dalam kajian Islam disebut ummatan washatan tersirat dalam Q.S. al-Baqarah (2): 143.

"Dan demikian (pula) Kami telah menjadikan kamu (umat Islam), umat yang adil dan pilihan agar kamu menjadi saksi atas (perbuatan) manusia dan agar Rasul (Muhammad) menjadi saksi atas (perbuatan) kamu. Dan Kami tidak menetapkan kiblat yang menjadi kiblatmu (sekarang) melainkan agar Kami mengetahui (supaya nyata) siapa yang mengikuti Rasul dan siapa yang membelot. Dan sungguh (pemindahan kiblat) itu terasa amat berat, kecuali bagi orang-orang yang telah diberi petunjuk oleh Allah; dan Allah tidak akan menyia-nyiakan imanmu. Sesungguhnya Allah Maha Pengasih lagi Maha Penyayang kepada manusia" (Qur'an 2.143).

Teori-teori prinsip dalam materi moderasi beragama yang pertama yaitu sikap tawassuth. Tawassuth merupakan sikap moderat sesuai akar katanya yang berarti tengah-tengah. Dengan kata lain, sikap tawassuth mengekspresikan sikap yang tidak ekstrim kanan maupun ekstrim kiri dalam mengambil pemahaman agama. Sikap kedua yaitu tasamuh yang diartikan sebagai sikap toleran dalam bertindak. Toleran bukan berkaitan dengan akidah, melainkan sikap bijak dalam bermasyarakat yang plural.

Sikap ketiga yaitu i'tidal yang berarti tegas atau lurus. i'tidal lazimnya menjadi istilah dalam salah satu rukun salat. Sikap tegas dalam beraikdah termasuk menentang kelompok ekstrim merupakan pengamalan dari sikap i'tidal. Sikap keempat dalam moderasi beragama adalah sikap egaliter atau musawah. Egaliter merupakan sikap sosial yang selalu dicontohkan oleh para nabi- nabi Allah Swt khususnya nabi Muhammad Saw. Sikap-sikap selanjutnya yaitu semangat bermusyawarah atau syura, mendahulukan kepentingan orang banyak atau alawiyah, inovatif dan progresif atau tathawwir wa ibtikar serta berkeadaban tinggi atau tahadhdhur (Syifa, 2019).

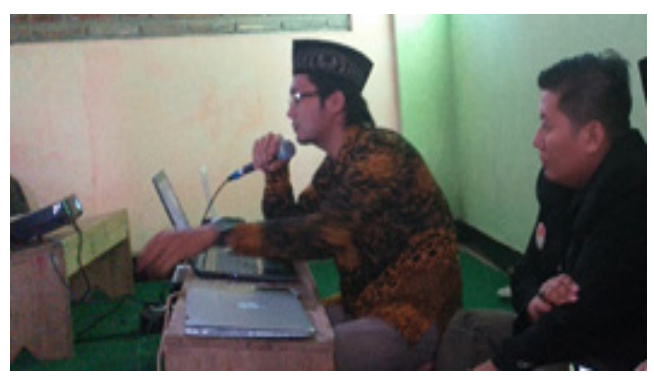

Gambar 2: Pemaparan materi dasar moderasi beragama

Sesi ketiga berjalan selama 90 menit dengan 50 menit materi dan 40 menit diskusi. Sesi ketiga diakhiri dengan pemaparan dari masing-masing peserta tentang konsep moderasi dari masing-masing ajaran agama dan kepercayaan peserta yang berbeda satu sama lainnya.

\section{Sesi 4}

Sesi keempat dilaksanakan setelah istirahat salat zuhur berjama'ah bagi yang muslim, dan makan siang. Materi keempat disampaikan oleh Ahmad Yusuf Prasetiawan, dosen Fakultas Teknik Universitas Jenderal Soedirman. Tema materi pada sesi keempat adalah bagaimana remaja cerdas memanfaatkan literasi media digital. Remaja merupakan konsumen aktif media sosial. Konsumsi media sosial erat kaitannya dengan kebutuhan remaja milenial yang lebih familiar dengan sebutan generai milenial. Generasi milenial merupakan generasi yang terbuka dan cenderung permisif terhadap berbagai informasi di media sosial (Republika, 2016). 
Pertama, peserta mendapatkan berbagai informasi isu intoleransi yang aktual, berita hoax, serta hasutan kebencian di media sosial. Salah satu fenomena yang memprihatinkan bahwa kasus-kasus tersebut membawa dan mengatasnamakan agama tertentu. Tidak sedikit pula para pemuka agama yang justru menjadi pelopor informasi hoax dan mengajak kebencian dan pada kelompok tertentu yang mereka menyasar generasi muda (Yahya \& Farhan, 2019).

Bagian kedua dari sesi keempat adalah analisis hoax dan ujaran kebenjian di media sosial yang berdampak pada masyarakat di kehidupan nyata. Dampak negatif dari hoax dan ujaran kebencian juga sangat mengena pada remaja. Remaja pengadopsi berita bohong atau ujaran kebencian secara alam bawah sadar terpacu untuk menyebarluaskannya ke dalam komunitas sosial mereka. Selain itu puncak dari ujaran kebencian adalah perilaku sewenang-wenang remaja dalam mengekspresikan ketidak setujuan mereka terhadap suatu kebijakan, baik di keluarga maupun kebijakan negara (Triastuti et al., 2017).

Akhir sesi keempat menjadi refkleksi bersama antara pemateri dengan peserta tentang bagaimana sikap seharusnya seorang remaja menghadapi banyaknya ancaman negatif di media sosial. Urgensi pemaparan materi intoleransi dan berita bohong di media sosial ini adalah bagaimana peserta dapat menempatkan diri dan berperan aktif menyebarkan isu positif melalui media sosial. Refleksi menjadi penutup pada workshop sesi keempat.

\section{Sesi 5}

Sesi kelima berisi materi media literasi digital. Materi disampaikan oleh Susanto, perwakilan Forsa Banyumas yang juga merupakan jurnalis media cetak dan elektronik surat kabar di Banyumas. Literasi digital merupakan kajian dalam upaya memberikan pemahaman teknis dalam mengolah informasi di media digital (Caniago, 2013). Materi literasi media digital memiliki urgensi dalam membentuk karakter generasi milenial yang tanggap terhadap dampak negatif media digital. Pada sesi kelima ini peserta mendapat pelatihan dalam mencari dan menganalisis konten yang berorientasi sara. Setelah pada sesi sebelumnya peserta mendapatkan pemahaman dari dampak konten sara berupa hoax, intoleran dan ujaran kebencian di tengah masyarakat. Peserta mendapat pelatihan dalam mencari informasi akurat dari suatu berita yang trending di masyarakat. Pemateri membimbing peserta untuk menulusuri fakta berita atau informasi menggunakan media mainstream. Peserta mendapatkan keterampilan teknis mengelola suatu informasi melalui penelusuran informasi yang kredibel. Sesi kelima diakhiri oleh panitia dengan memberikan waktu kepada peserta untuk istirahat sejenak sebelum peserta mengikuti post-test.

\section{Sesi 6}

Sesi keenam dari workshop merupakan sesi evaluasi dan pengukuran hasil workshop. Bntuk evaluasi menggunakan post-test. Materi yang diujikan oleh panitia merupakan materi yang telah diujikan sebelumnya dalam pre-test. Hasil post-test menunjukkan angka kenaikan pemahaman peserta workshop dari semula pada tingkat pemahaman "medium" menjadi tingkat pemahaman "tinggi". 


\section{Sesi 7}

Rangkaian pengabdian masyarakat pada sesi ketujuh dikemas dengan kegiatan out door. Kegiatan ini melibatkan peserta workshop dalam kegiatan sesi kesatu sampai sesi keenam. Kegiatan berbentuk turun jalan atau turjal dalam merespon situasi Pandemi Covid 19. Kegiatan berbentuk partisipasi pembagian makanan siap saji, sembako, dan masker untuk masyarakat di Banyumas. Masyarakat yang menjadi sasaran kegiatan terdiri dari pengelola rumah ibadah dan masyarakat yang berprofesi sebagai pedaqgang kaki lima, tukang becak serta tukang parkir di sekitar rumah ibadah. Tujuan dari kegiatan ini adalah untuk menumbuhkan sikap kepedulian bersama kepada peserta pelatihan workshop moderasi beragama.

Peserta turjal selain membagikan sembako dan masker juga memberikan edukasi langsung kepada para pengelola tempat ibadah. Sesuai anjuran pemerintah, tempat ibadah menjadi salah satu tempat yang mudah menimbulkan kerumunan dan dapat menjadi cluster penyebaran Covid 19. Pemerintah juga menghimbau pada pengelola tempat ibadah untuk secara disiplin dalam penanggulangan Covid-19 serta sementara meniadakan kegiatan ibadah yang berkerumun untuk wilayah-wilayah dengan zona merah terpapar Covid-19 (intan limbong, 2020).

\section{Sesi 8}

Sesi terakhir dalam rangkaian sesi kegiatan pengabdian masyarakat dengan tema penguatan moderasi beragama di kalangan remaja pada masa Covid-19 ditutup dengan sesi kedelapan. Sesi ini menjadi sesi pelengkap pada kegiatan praktik lapangan.
Kegiatan sesi kedepalan berupa siaran radio secara langsung perwakilan tim pengabdian dari Unsoed dan di presidium Forsa Banyumas. Kegiatan terselenggara pada hari Rabu, tanggal 13 Mei 2020.

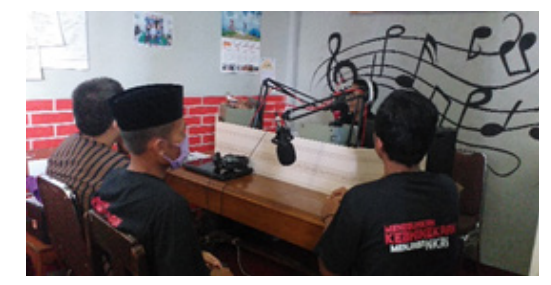

Gambar 3: On-air deklarari pemuda lintas iman peduli Covid 19 di Radio Rama FM.

Ketua tim pengabdian masyarakat Unsoed, Muhamad Riza Chamadi menyampaikan pentingnya membangun komunikasi antar masyarakat agama dalam upaya pencegahan Covid 19. Sedangkan Alfian selaku perwakilan Forsa Banyumas menyampaikan rangkaian acara pengabdian dengan mitra Unsoed dimulai dari workshop, pembagian masker dan sembako, serta penutup yaitu pada acara on-air tersebut melalui radio swasta Rama FM. Menurut Alfian, radio merupakan media komunikasi yang mudah diakses oleh oleh masyarakat lokal (Suarabanyumas.com, 2020).

\section{Kesimpulan}

Kesimpulan yang dapat diperoleh dari kegiatan pengabdian masyarakat dengan judul "Penguatan Moderasi Beragama melalui Forum Persaudaraan Lintas Iman (Forsa) Kabupaten Banyumas pada Masa Pandemi Covid 19" adalah keberhasilan penguatan pemahaman remaja lintas iman terhadap moderasi beragama. Evaluasi kegiatan melalui pre-test dan post-test menunjukkan kenaikkan grade pemahaman yang semula pada skalam medium berubah menjadi skala tinggi. Peserta pelatihan memberikan kesan dan pesan yang 
positif setelah mengikuti kedelapan sesi kegiatan. Berdasarkan simpulan tersebut, tim pengabdian Universitas Jenderal Soedirman memberikan saran-saran sebagai berikut:

1. Remaja merupakan fase strategis dalam menngedukasi baik-buruknya suatu konteks permasalahan. Orang tua memiliki peran vital dalam mengedukasi dan mengawasi perkembangan perilaku anak-anak mereka yang telah menuju fase remaja. Untuk itu perlu kesadaran orang tua dalam mengetahui karakteristik pergaulan anak-anak mereka sesuai perkembangan jaman.

2. Perkembangan dakwah keagamaan di era digital sudah banyak memiliki pengikut dari kalangan remaja. Untuk itu idealnya para penceramah atau da'i milenial mampu menyajikan materi dakwah yang menyejukkan dan memotivasi remaja untuk menjadi orang yang bijak, baik dalam agama maupun dalam kehidupan sosial kemasyarakatan.

3. Pemerintah memiliki peran legislasi dalam mengawasi berbagai konten media sosial yang mengancam kehidupan berbangsa dan bernegara. Oleh karena itu ketegasan pemerintah dalam menyaring konten-konten negatif di jejaring sosial, merupakan salah satu cara untuk menyajikan media sosial yang ramah untuk kalangan remaja.

\section{Ucapan Terima Kasih}

Tim pengabdian masyarakat Universitas Jenderal Soedirman menyampaikan ucapan terima kasih setinggi-tingginya kepada LPPM (Lembaga Penelitian dan Pengabdian Masyarakat LPPM Universitas Jenderal Soedirman, yang telah merealisasi pendanaan
PKM penerapan iptek dan memberikan kesempatan kepada tim pengabdi dalam merealisasikan kegiatan ini. Terima kasih juga tim pengabdi sampaikan kepada Forum Persaudaraan Lintas Iman (Forsa) Kabupaten Banyumas yang telah menjadi mitra yang sangat baik dalam merealisasikan kegiatan pengabdian ini.

\section{Daftar Pustaka}

Abdullah, A. (2016). Gerakan Radikalisme Dalam Islam: Perspektif Historis. Addin, 10(1), 1. https://doi.org/10.21043/ addin.v10i1.1127

Akhmadi, A. (2008). Moderasi Beragama dalam Keragaman Indonesia. 13(2), 4555.

Busyro, B., Ananda, A. H., \& Adlan, T. S. (2019). Moderasi Islam (Wasathiyyah) di Tengah Pluralisme Agama Indonesia. FUADUNA: Jurnal Kajian Keagamaan Dan Kemasyarakatan, 3(1), 1. https:// doi.org/10.30983/fuaduna.v3i1.1152

Caniago, J. K. (2013). Literasi Media dan Literasi Digital. FIB, Universitas Sumatera Utera, 53(9), 1689-1699.

Diananda, A. (2018). Psikologi Remaja dan Permasalahannya. ISTIGHNA, 1(1), 116133.

Dugard, P., \& Todman, J. (1995). Analysis of Pre-test-Post-test Control Group Designs in Educational Research. Educational Psychology, 15(2), 181-198. https://doi. org/10.1080/0144341950150207

Faiqah, N., \& Pransiska, T. (2018). Radikalisme Islam Vs Moderasi Islam: Upaya Membangun Wajah Islam Indonesia Yang Damai. Al-Fikra: Jurnal Ilmiah Keislaman, 17(1), 33. https://doi. 
org/10.24014/af.v17i1.5212

intan limbong. (2020). Dampak Pandemi Covid19 Terhadap Ibadah di Indonesia. http://dx.doi.org/10.31219/osf. io/3vcu7

Juhri, M. A. (2020). Paradigma Tauhid sebagai Basis Mewujudkan Moderasi Islam Di Indonesia. Jurnal Ilmiah Mahasiswa Raushan Fikr, 9(2), 1-9.

Jumala, N. (2019). Moderasi Berpikir untuk Menempati Tingkatan Spiritual Tertinggi dalam Beragama. 21, 170-184.

Latif, Y. (2011). Negara Paripurna (I. S. Ibrahim (ed.); I). Gramedia.

Maliki, M. (2020). Covid-19, Agama, dan Sains. Maarif, 15(1), 60-92. https://doi. org/10.47651/mrf.v15i1.77

Mubarok, A. A., \& Rustam, D. G. (2018). Islam Nusantara: Moderasi Islam di Indonesia. Jurnal of Islamic, 3(2), 153-168. http:// journal.walisongo.ac.id/index.php/jish

Pakpahan, A. K. (2020). Covid-19 dan Implikasi Bagi Usaha Mikro, Kecil, Dan Menengah. Jurnal Ilmiah Hubungan Internasional, 0(0), 59-64. https://doi.org/10.26593/ jihi.v0i0.3870.59-64

Pursika, I. N. (2009). Kajian Analitik Terhadap Semboyan "Bhinneka Tunggal Ika". Jurnal Pendidikan Dan Pengajaran, 42(1), 15-20.

Republika. (2016). Mengenal Generasi Millennial. http://www.republika. co.id/berita/koran/inovasi/16/12/26/ ois64613-mengenal-generasi-millennial

Riduwan, A. (2016). Pelaksanaan Kegiatan Pengabdian. EKUITAS (Jurnal Ekonomi Dan Keuangan), 3. https://doi.org/DOI: 10.24034/j25485024.y1999.v3.i2.1886
Rogers, Y., \& Brig, H. (2002). Subtle icebreaking: encouraging socializing and interaction around a large public display. CSCW02 Workshop Proceedings, 1-6.

Shihab, M. Q. (2019). Wasathiyah: Wawasan Islam tentang Moderasi Beragama (Qamaruddin SF (ed.)). Lentera Hati.

Suarabanyumas.com. (2020). Sosialisasikan Pencegahan Korona, Forsa Pilih Radio Streaming.Suarabanyumas.Com.https:// suarabanyumas.com/sosialisasikanpencegahan-korona-forsa-pilih-radiostreaming/

Syifa, M. M. (2019). Formulasi Konsep Moderasi Islam berbasis Keindonesiaan dalam mereduksi Radikalisme Agama di Indonesia (Kajian EpistemologisHistoris). Raushan Fikr, 8(1), 31-41.

Triastuti, E., Andrianto, D., \& Nurul, A. (2017). Kajian Dampak Penggunaan Media Sosial bagi Anak dan Remaja. In Puskakom.

Umami, I. (2019). Psikologi remaja (1st ed.). IDEA Press.

Widyaningsih, R., Kuntarto, K., \& Chamadi, M. R. (2021). The Level of Religion Radicalism Understanding Among University Students in Banyumas Region. KOMUNIKA: Jurnal Dakwah Dan Komunikasi, 15(1), 39-53. https://doi. org/10.24090/komunika.v15i1.4169

Yahya, M., \& Farhan, F. (2019). Dakwah Virtual Masyarakat Bermedia Online. Briliant: Jurnal Riset Dan Konseptual, 4(2), 249. https://doi.org/10.28926/ briliant.v4i2.320 